\title{
Long-term maintenance of in vitro cultures affects growth and secondary metabolism of St. John's Wort
}

\author{
A manutenção prolongada de culturas in vitro afeta o crescimento e o metabolismo \\ secundário de hipérico
}

\author{
Adriana de Andrade Figueiró ${ }^{1}$ Cynthia Manira Correa ${ }^{1}$ \\ Leandro Vieira Astarita ${ }^{\mathrm{I}}$ Eliane Romanato Santarém ${ }^{\mathrm{I}^{*}}$
}

\begin{abstract}
Hypericum perforatum is a traditional medicinal plant with wound healing and antidepressant properties. Efficiency of micropropagation is often related to the long term maintenance of tissues in culture, which may alter the secondary metabolism of plants. The objective of this study was to evaluate growth and secondary metabolism of in vitro shoots of $\boldsymbol{H}$. perforatum on short and long term maintenance of cultures (30 and 100 days). The effect of BA and NAA supplementation was evaluated during 30 days of culture. Adventitious shoots were cultivated on MS medium supplemented with $4.4 \mathrm{mMBA}$ alone or in combination with $0.05 \mathrm{mM}$ NAA for 30 days. A hormone-free medium was used as control. Shoots cultivated for 100 days were maintained in presence of $4.4 \mathrm{mM}$ BA. Biomass, multiplication of shoots, contents of phenolic compounds, flavonoids and hypericin were evaluated. No difference between $B A$ and $B A+N A A$ was observed on growth, multiplication of shoots and levels of flavonoids at the end of 30 days of culture. Production of phenolic compounds was promoted by addition of $B A+N A A$ to the medium, whereas hypericin was increased by the presence of $B A$. The time of culture (30 and 100 days) affected all the parameters analyzed, except the levels of flavonoids in the short term experiment.
\end{abstract}

Key words: tissue culture, Hypericum perforatum, hypericin, phenolic compounds.

\section{RESUMO}

Hypericum perforatum é uma planta medicinal que apresenta propriedades cicatrizante e antidepressiva. Frequentemente, a eficiência da micropropagação está relacionada à manutenção dos tecidos em cultura por longos períodos, o que pode alterar o metabolismo secundário das plantas. $O$ objetivo deste trabalho foi avaliar o crescimento e o metabolismo secundário de brotações adventícias de $\boldsymbol{H}$. perforatum mantidas por diferentes tempos de cultivo $(30$ e 100 dias). $O$ efeito da adição de BA e ANA foi avaliado no período de 30 dias. As brotações foram cultivadas em meio MS suplementado com 4,4mM BA como único regulador ou em combinação com 0,05mM ANA, por 30 dias. Um meio de cultivo sem adição de reguladores foi utilizado como controle. As brotações cultivadas por 100 dias foram mantidas em presença de 4,4mM BA. A biomassa, a multiplicação dos brotos, as concentrações de compostos fenólicos, flavonoides $e$ hipericina foram os parâmetros avaliados. Nenhuma diferença entre a adição de BA ou BA+ANA foi observada quanto ao crescimento, ao número de brotos e aos níveis de flavonoides ao final de 30 dias de cultivo. Diferenças neste período foram detectadas nos níveis de compostos fenólicos e de hipericina quando os brotos foram cultivados em presença de BA+NAA e de $B A$, respectivamente. $O$ tempo de cultivo (30 e 100 dias) afetou todos os parâmetros avaliados, com exceção dos níveis de flavonoides no período de 30 dias.

Palavras-chave: cultura de tecidos, Hypericum perforatum, hipericina, compostos fenólicos.

\section{INTRODUCTION}

Hypericum perforatum $\mathrm{L}$. is a medicinal plant with antidepressant, antiviral, wound healing, antimicrobial, antioxidant and anti-tumoral proprieties (BRUNI \& SACCHETTI, 2009). These biological activities are related to the secondary metabolites produced by the plant, including naphthodianthrones (hypericin and pseudohypericin), acylphloroglucinols

'Departamento de Biologia Celular e Molecular, Faculdade de Biociências, Pontifícia Universidade Católica do Rio Grande do Sul (PUCRS). Av. Ipiranga, 6681, Prédio 12C, 90619-900, Porto Alegre, RS, Brasil. E-mail: esantarem@pucrs.br. *Autor para correspondência. 
(hyperforin and adhyperforin) and flavonols (quercetin and its glycosides). Hypericin, the main component of $\boldsymbol{H}$. perforatum, has been extensively studied as a multifunctional agent in medicinal applications. Likewise, flavonoids are pharmacologically active compounds and also act as co-effectors to improve the biopharmaceutical properties of hypericin (BUTTERWECK \& SCHMIDT, 2007).

The increasing demand for the bioactive compounds of $\boldsymbol{H}$. perforatum as well as the variable content of these molecules often observed in pharmaceutical preparations have triggered the exploration for biotechnological strategies that could increase the commercial production of specific compounds. In vitro systems have been reported as an effective tool for obtaining genetically uniform plants and have empowered the manipulation of the biosynthesis of several secondary compounds. Resembling the influence that the natural environment plays on H.perforatum plants (COUCEIRO et al., 2006), physical culture conditions, explants type and media employed in the protocols for tissue culture are factors that might participate on the regulation of the secondary metabolism of this species (BAIS et al., 2002; SANTAREM \& ASTARITA, 2003; WOJCIK \& PODSTOLSKI, 2007).

Biosynthesis and accumulation of secondary compounds, mainly hypericin and flavonoids, have been related to cell differentiation, attaining their highest levels during leaf morphogenesis. Hypericin and flavonoids were found in leaves of adventitious shoots of $\boldsymbol{H}$. perforatum, although only little amounts were detected in cell masses (PASQUA et al., 2003; SANTAREM \& ASTARITA, 2003; KARPPINEN et al., 2006; MACHADO et al., 2007). Thereby, systems involving adventitious shoots or whole plants are likely more suitable for production of specific secondary metabolites. In spite of the numerous reports on tissue culture of $\boldsymbol{H}$. perforatum, little is known about the effects of extended periods of culture on the production of secondary compounds in this species. Most of the studies were carried on using 21 to 25 -day intervals, corresponding to one subculture period (PASQUA et al., 2003; ZOBAYED et al., 2004; CONCEIÇÃO et al., 2006). Thus, the aim of this study was to evaluate the differences between short and long term-maintenance cultures regarding growth and secondary metabolism of in vitro shoots of $\boldsymbol{H}$. perforatum. The effect of plant growth regulators, benzyladenine (BA) and naphthalene acetic acid (NAA), on secondary metabolism were also tested.

\section{MATERIAL AND METHODS}

Adventitious shoots of $\boldsymbol{H}$. perforatum $\mathrm{L}$. were induced from nodal segments as described by SANTAREM \& ASTARITA (2003). Induced shoots were propagated on semi-solid MS (MURASHIGE \& SKOOG, 1962) medium with addition of 4.4mMBA. Clusters of adventitious shoots (3g) were cultivated on MS basal medium, either supplemented with $4.4 \mathrm{mM}$ BA alone, or in combination with $0.05 \mathrm{mM}$ NAA. A hormone-free medium was used as a control. A shortterm experiment (30 days) was established, and shoot clusters were analyzed every five days for biomass accumulation, shoot multiplication, and levels of total phenolic compounds, quercetin-derived flavonoids and hypericin. Shoot growth was evaluated through the increment of fresh mass (g FM) and the number of adventitious shoots per cluster. No subculture was carried out within the 30 days. An extended period of in vitro culture was also evaluated (long-term experiment) where shoots were cultured on MS medium with $4.4 \mathrm{mM} \mathrm{BA}$ for 100 days and subcultured every 20 days. The same parameters mentioned for the shortterm experiment were analyzed at the time of each subculture, consisting of six time points of observation. Sucrose $\left(30 \mathrm{~g} \mathrm{~L}^{-1}\right)$ and agar $\left(6 \mathrm{~g} \mathrm{~L}^{-1}\right)$ were added to all media. Cultures were maintained at $26 \pm 1^{\circ} \mathrm{C}$ under a 16 -h photoperiod of $15 \mathrm{mE} \mathrm{m}^{-2} \mathrm{~s}^{-1}$ of irradiance.

Samples of $1 \mathrm{~g}$ FM of shoots were homogenized in $10 \mathrm{~mL}$ of $80 \%(\mathrm{v} / \mathrm{v})$ aqueous methanol for quantitative analysis of the total phenolic compounds and quercetin-derived flavonoids following POIATTI et al. (2009). Hypericin was extracted with in $100 \%$ methanol and determined by HPLC, as reported by SANTAREM \& ASTARITA (2003).

Experiments were independently repeated twice under the same conditions. The effect of the culture period was evaluated by regression analysis and ANOVA, whereas the effect of growth regulators, BA and NAA, was analyzed by ANOVA and multiple comparison of means was accomplished with Tukey's test $(\alpha=0.05)$. Correlation between biomass and number of shoots was evaluated by Pearson Correlation Test. Statistical analyses were performed with the SPSS statistical software program (SPSS v.11.5).

\section{RESULTS AND DISCUSSION}

Growth of shoot clusters of $\boldsymbol{H}$. perforatum was observed during the cultivation for 30 days without subculture on medium supplemented either with BA or BA+NAA. Adventitious shoots cultured 
on hormone-free medium did not proliferate and developed roots. The effect of growth regulators could be observed for both biomass accumulation and shoot multiplication, when compared to the control (Figure $1 \mathrm{~A}$ and $\mathrm{B})$. The period of culture positively influenced biomass and shoot multiplication. At day 15, a 2-fold increase of biomass was recorded, reaching an average of 2.8-fold by the end of the short-term culture (Figure 1A). Through regression analysis, the daily increase of fresh weight was predicted to be $0.216 \mathrm{~g}$ and $0.197 \mathrm{~g}$ on media supplemented with BA and BA+NAA, respectively. Similarly to the increase of biomass, a significant 3-fold increase in the number of adventitious shoots was also observed after 30 days of culture either with BA or BA+NAA supplementation (Figure1B).

Although growth and multiplication of shoots were analyzed separately, the Pearson's correlation indicated a positive relationship between biomass and number of shoots $\left(\mathrm{R}^{2}=0.99\right.$ and 0.96 for $\mathrm{BA}$ and BA+NAA-containing medium, respectively).
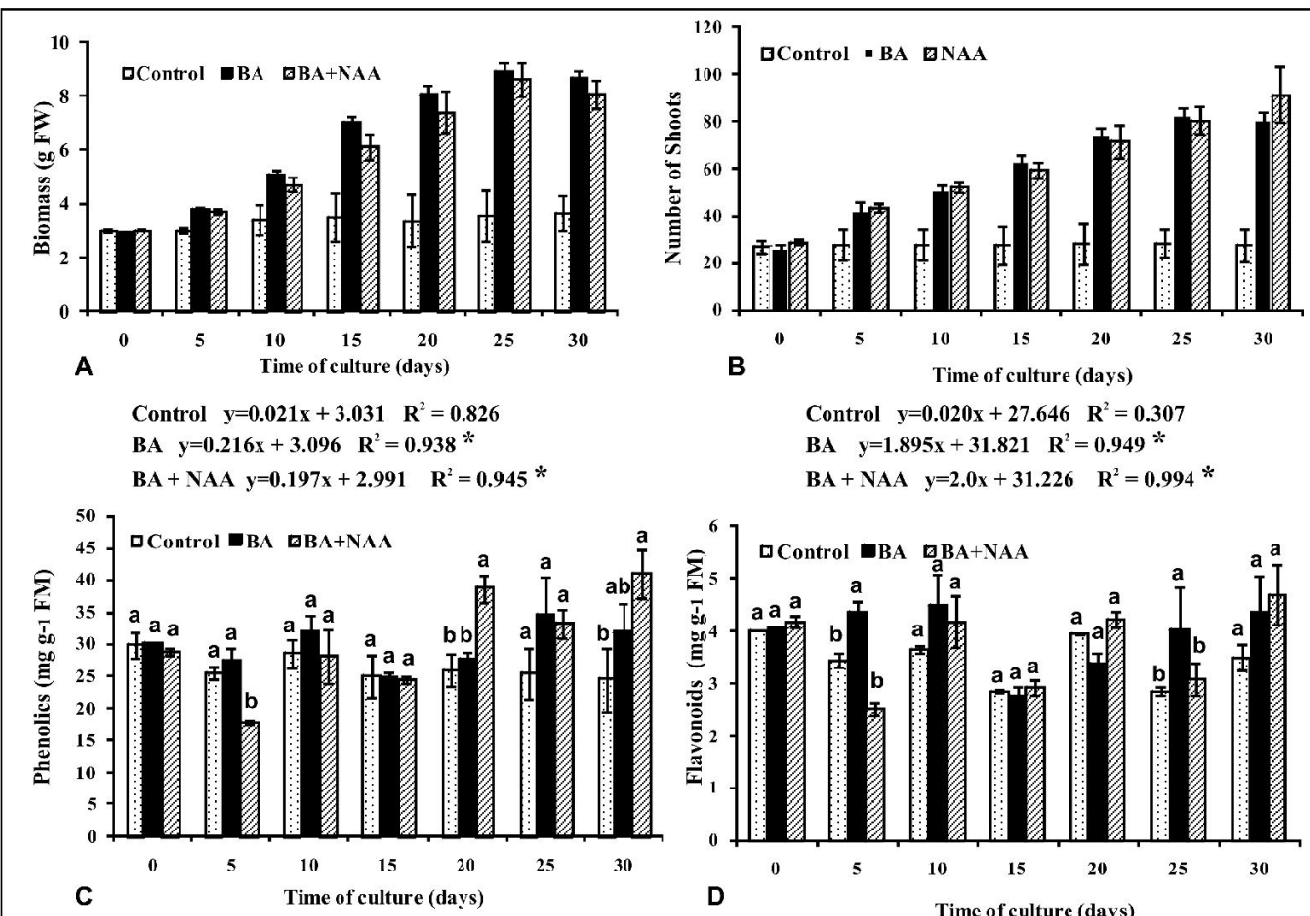

Control $y=-0.667 x+29.086 R^{2}=0.520$

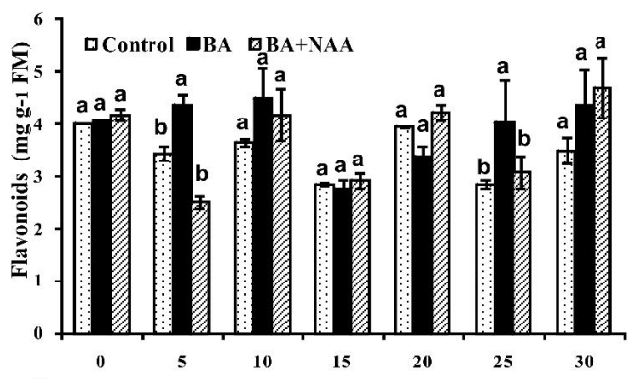

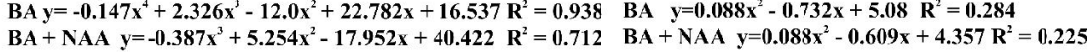

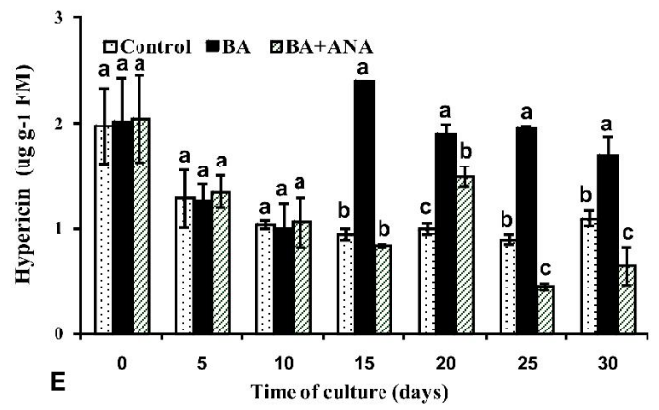

Control $y=-0.0001 x^{3}+0.007 x^{2}-0.153 x+1.951 \quad R^{2}=0.972 *$

BA $y=4 E-05 x^{4}-0.0026 x^{3}+0.059 x^{2}-0.434 x-2.063 \quad R^{2}=0.760 *$

BA + NAA $y=-0.0002 x^{3}+0.0105 x^{2}-0.178 x+2.027 R^{2}=0.732 *$

Figure 1 - Biomass (A), shoot multiplication (B), total phenolic compounds (C), flavonoids (D) and hypericin (E) of adventitious shoots of $\boldsymbol{H}$. perforatum, cultured on MS medium supplemented with $4.4 \mathrm{mM}$ $\mathrm{BA}$ or $4.4 \mathrm{mM} \mathrm{BA}+0.05 \mathrm{mM}$ NAA during 30 days. Data are presented as the mean $( \pm \mathrm{SE})$ of either 15 ( $\mathrm{A}$ and $\mathrm{B}$ ) or six replicates (C to $\mathrm{E}$ ). Bars signalized with the same letter are not significantly different between treatments in each time point $(\mathrm{P} \leq 0.05)$. Equations of regression are shown for each parameter. Significance is indicated by an asterisk $(\mathrm{P} \leq 0.05)$. 
Production of phenolic compounds by adventitious shoots of $\boldsymbol{H}$. perforatum was affected by the interaction between the period of culture and the addition of BA+NAA to the medium. A significant increase in the levels of phenolic compounds during the period of culture was observed from days 20 to 30 in the shoots cultivated on BA+NAA (ranging from $33.2 \mathrm{mg} \mathrm{g}^{-1} \mathrm{FM}$ to $35.3 \mathrm{mg} \mathrm{g}^{-1} \mathrm{FM}$; Figure $1 \mathrm{C}$ ). On the contrary, in spite of the variation on the fraction of flavonoids (from 2.84 to $4.52 \mathrm{mg} \mathrm{g}^{-1} \mathrm{FM}$; Figure 1D), no significant difference was obtained with the time of culture. The influence of growth regulators was detected twice along the cultivation, when the addition of BA induced accumulation of flavonoids at 5 and 25 days (Figure 1D). Variation in the content of hypericin in the adventitious shoots of $\boldsymbol{H}$. perforatum resulted from a significant interaction between the culture period and treatments. Similar to the control treatment, the supplementation of BA+NAA resulted in decreased levels of hypericin during the time of cultivation (Figure 1E). On the other hand, addition of BA to the medium induced the production of hypericin from day 15 onwards (Figure 1E).
Cultivation of adventitious shoots in presence of $\mathrm{BA}$ for 100 days promoted multiplication of adventitious shoots of $\boldsymbol{H}$. perforatum. A gradual increase in biomass was observed up to day 40 , and after this time point, a marked increase was recorded; the highest amount of biomass was obtained at day 100 (Figure 2A). Through regression analysis, the increment of biomass was determined as $0.381 \mathrm{~g}$ of FM per day (Figure 2A). Similarly, multiplication of adventitious shoots was also promoted by long-term cultivation, and a 2-fold increase in the number of shoots was observed within 20 days of culture. No significant increase on the number of shoots was observed at 60 and 80 days of culture, likely because of the partial death of the shoot cluster. Necrosis of the tissue may have been caused by the high number of shoots per flask. When shoot clusters from each culture flask were divided into two flasks, growth was recovered. Clusters maintained in culture for 100 days reached an average of 199.7 shoots (Figure 2B), as a consequence of an increment of 1.4 shoots per day. Similarly to that observed in the 30-day experiment, Pearson's correlation indicated a strong positive

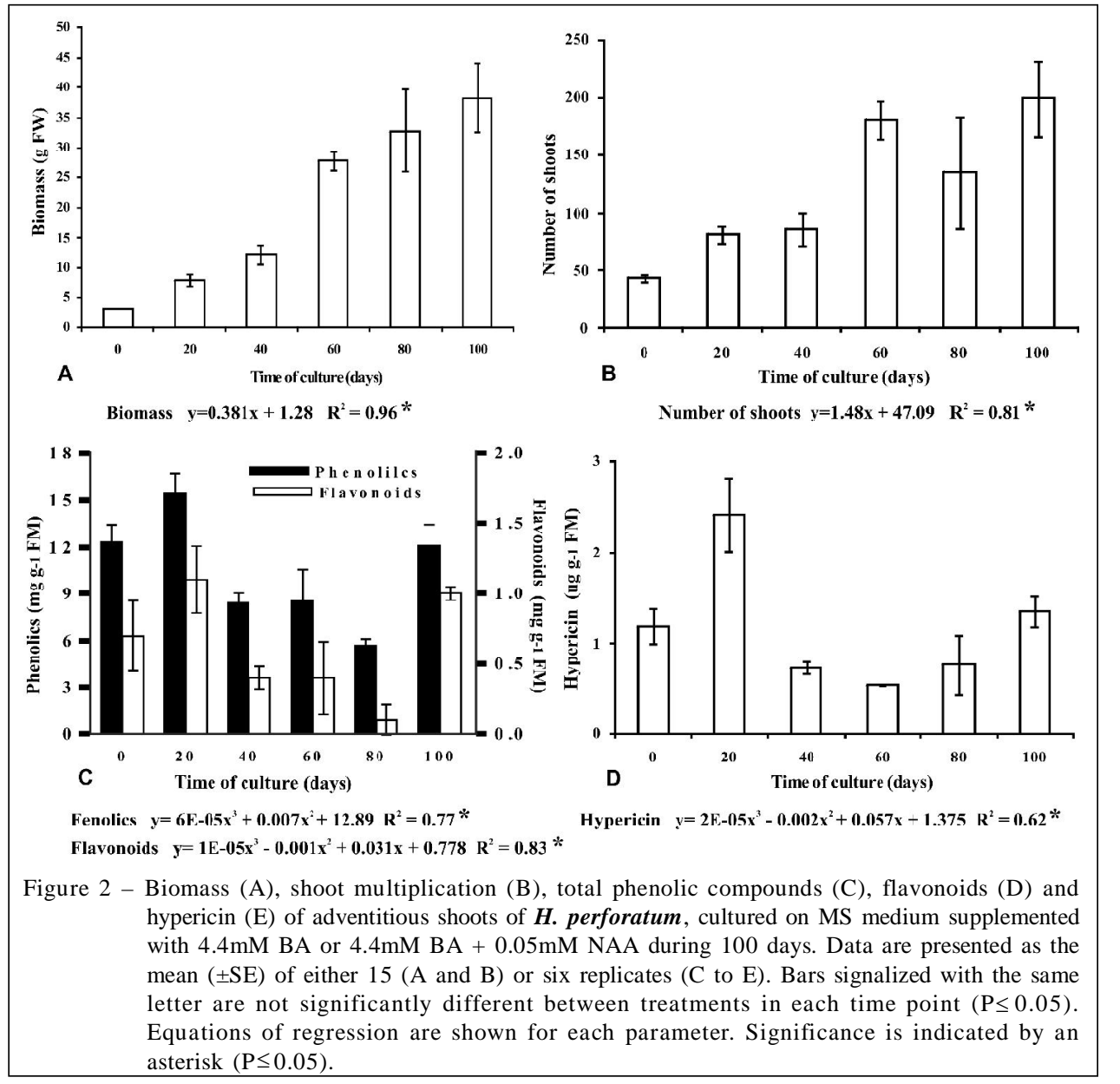

Ciência Rural, v.40, n.10, out, 2010. 
relationship between growth and multiplication of shoots $\left(\mathrm{R}^{2}=0.98\right)$.

The period of culture seemed to influence the production of secondary metabolites by shoots of $\boldsymbol{H}$. perforatum. Levels of phenolic compounds and flavonoids were significantly higher at day 20 and day 100 (Figure 2C). Accumulation of hypericin also varied along the culture, showing a 2.5 -fold increase at day 20.

The evolving commercial interest in $\boldsymbol{H}$. perforatum has driven the studies on the establishment of efficient alternatives, such as in vitro tissue culture, to increase the propagation of elite germplasm and accumulation of secondary metabolites. In spite of the numerous reports in tissue culture, $\boldsymbol{H}$. perforatum remains intensively studied because of the great variation among culturing systems used (BAIS et al., 2002; SANTARÉM \& ASTARITA, 2003; ZOBAYED et al., 2004).

The composition of the medium is an important factor studied to optimize the micropropagation of $\boldsymbol{H}$. perforatum. Other than culture conditions, studies have reported that growth regulators significantly affect growth and multiplication (KARPPINEN et al., 2006; LIU et al., 2007). In most species, a high cytokinin/auxin ratio is required for shoot regeneration. However, in our 30-day system, supplementation of culture medium with auxin did not increase the overall growth of $\boldsymbol{H}$. perforatum compared to the use of $\mathrm{BA}$ as the only growth regulator. Considering that hormone-free medium did not induce growth, BA is likely the growth regulator affecting the propagation in the system tested. It is known that cytokinins are involved in the promotion of cell division and in overcoming apical dominance, releasing the lateral bud from dormancy (D'AGOSTINO \& KIEBER, 1999). Among cytokinins, BA has been the most effective shoot-inducing agent in several species studied, although the combination of BA with auxins (NAA and IBA) has also been used to induce shoot multiplication of $\boldsymbol{H}$. perforatum and other medicinal species (SANTARÉM \& ASTARITA, 2003; DEBNATH et al., 2006; LIU et al., 2007; WOJCIK \& PODSTOLSKI, 2007).

At the metabolic level, supplementation with BA did not affect significantly the accumulation of phenolic compounds and the fraction of flavonoids during the 30-day time course. On the other hand, addition of BA+NAA had a positive effect on phenolic accumulation after 20 days of culture. It has been reported that different concentrations and types of growth regulators may have an effect in the synthesis and/or accumulation of secondary metabolites. The influence of auxins and cytokinins on the activity and expression of enzymes from the phenylpropanoid pathway has been studied, and the activities of phenylalanine ammonium lyase (PAL) and chalcone synthase were shown to be inhibited by auxin, whereas the $c h s$ gene was induced by cytokinin (SCHMÜLLING et al., 1997). Contrarily, results showed that the auxin NAA added to the medium increased the accumulation of phenolics, probably by activating PAL and overall BA did not affect the synthesis of flavonoids. However, little is known about the effect of cytokinins on the regulation of phenolics and the fraction of quercitinderived flavonoids. Moreover, the role of the phytohormone balance in controlling the level of phenylpropanoids in plants is likely to be associated with other variables inherent to the tissue-culture process.

Unlike the phenolics, hypericin production was increased by the presence of BA in the culture medium, and the variation observed was mostly related to the period of culture. Likewise, an earlier study with $\boldsymbol{H}$. perforatum reported increases in hypericin and pseudohypericin levels in shoots grown on BAcontaining medium, suggesting that stimulation of hypericin production by $\mathrm{BA}$ is probably due to the increase in the number of dark glands in the leaves of the in vitro shoots (GADZOVSKAet al., 2005). Similarly, cytokinin regulation in micropropagated shoots resulted in increased levels of hypericin (LIU et al., 2007). Certainly, the use of cytokinins affects the growth, development, and photosynthetic rates of micropropagated shoots, which might be the reason for the highest level of hypericin obtained when shoots were cultivated on medium supplemented with BA.

Besides the growth regulators, the period of culture and, therefore, the time point of assaying the culture also have an important effect on determination of the levels of secondary metabolites. This has been confirmed by BAIS et al. (2002), who reported an increase in the hypericin level related to the accumulation of biomass in cell cultures of $\boldsymbol{H}$. perforatum during a time course of 28 days. In that system, cells were being cultured and no differentiation occurred. The data obtained in this study did not indicate a relationship between biomass and hypericin, because a linear increase in hypericin accumulation was not observed with continuous growth.

The extended period of culture resulted in a significant increase of biomass production and more shoots formed over time. By day 80, growth and multiplication were reduced, presumably because of 
the limitation imposed by the association between the increased number of shoots and the size of the vessel used for the culture. Hence, at this time point, clusters of shoots were divided into two batches, thus avoiding accumulation of ethylene and further necrosis of the tissue. After that, the growth was recovered. The longterm cultivation affected the accumulation of secondary metabolites, such as phenolic compounds and hypericin. The contents of phenolic compounds, including flavonoids, increased by day 20 compared to day 0 , and subsequently showed a significant decrease. The lower contents of these compounds observed at day 80 might be related to the oxidation of tissue caused by the restraint of the vessel. Hypericin displayed a similar pattern of accumulation over time. In fact, if a relationship is evaluated between the level of hypericin and the biomass accumulation, a decrease in this ratio was observed from days 20 to 40 , indicating that the shoots were using the energy for growth and multiplication rather than accumulating secondary metabolites. Because production and accumulation of hypericin are related to leaf differentiation, it is not surprising that shoots that are being stimulated to multiply do not show an increase in the synthesis of this compound.

Efficient production of phytochemical in cell/tissue cultures is determined by factors such as growth rate and explant selection, which regulate the synthesis of secondary metabolites (BAIS et al., 2002). Most of the in vitro systems evaluate growth and secondary metabolism after short periods of cultivation, but the efficient micropropagation for commercial application requires that tissues and adventitious shoots should be maintained in culture for longer periods of time. Plants with slow growth may be cultured on the same medium for extended periods and have increased production of secondary metabolites (MAURMANN et al., 2008). However, most herbal plants exhibit high multiplication rates under in vitro conditions, and the tissue manipulation and the repetitive subcultures may have an effect on the plant. Even promoting growth and multiplication, these aspects might be the cause of some type of stress and consequently alterations in the secondary metabolism of $\boldsymbol{H}$. perforatum. This study found a slight increase of phenolic compounds and hypericin after 80 days of cultivation, immediately after the subculture where the clusters were broken up, suggesting that shoots of $\boldsymbol{H}$. perforatum in long-term maintenance cultures may need frequent subcultures maintained in small clusters in order to keep stable the production and accumulation of bioactive compounds.

\section{ACKNOWLEDGMENTS}

This research was supported by Conselho Nacional de Pesquisa $(\mathrm{CNPq})$ /Brazil and Fundação de Amparo à Pesquisa do Estado do Rio Grande do Sul (FAPERGS)/Brazil.

\section{REFERENCES}

BAIS, H.P. et al. Factors affecting growth of suspension culture of Hypericum perforatum L. and production of hypericin. In Vitro Cellular and Developmental Biology - Plant, v.38, p.58-65, 2002.

BRUNI, R.; SACCHETTI, G. Factors affecting polyphenol biosynthesis in wild and field grown St. John's Wort (Hypericum perforatum L.). Molecules, v.14, p.682-725, 2009. Available in: <http://www.mdpi.com/1420-3049/14/2/682/>. Access: Dec. 20, 2009. doi: 10.3390/molecules14020682.

BUTTERWECK, V.; SCHMIDT, M. St. John's wort: Role of active compounds for its mechanism of action and efficacy. Wiener Medizinische Wochen, v.157, p.356-361, 2007. Available in: <http://www.springerlink.com/content/k75874h402932056/>. Access: Oct. 29, 2008. doi: 10.1007/s10354-007-0440-8.

CONCEIÇÃO, L.F.R. et al. Induction of phenolic compounds in Hypericum perforatum L. cells by Colletotrichum gloeosporioides elicitation. Phytochemistry, v.67, p.149155, 2006. Available in: <http://www.sciencedirect.com/ science?_ob=ArticleURL\&_udi=B6TH4HP6GC52\&_user=685977\&_ coverDate $=01 \% 2 \mathrm{~F} 31 \% 2 \mathrm{~F} 2006 \&$ _rdo= $=1 \&$ _fmt $=$ high \&_orig $=$ search \&_sort $=$ d\&_docanchor $=\&$ view $=$ c \&_acct $=$ C000037098 \&_version=1\&_urlVersion $=0 \& \_u s e r i d=685977 \& \mathrm{md} 5=3$ dee $3 \mathrm{af9e} 4 \mathrm{ff} 027 \mathrm{c0}$ 19ef46342bfb1fa>. Access: Aug. 27, 2007. doi: 10.1016/ j.phytochem.2005.10.017.

COUCEIRO, M.A. et al. Variation in concentrations of major bioactive compounds of St. John's wort: Effects of harvesting time, temperature and germplasm. Plant Science, v.170, p.128-134, 2006. Available in: <http://www.sciencedirect.com/ science? ob=ArticleURL\&_udi=B6TBH-4H2FWW6$1 \&$ _user $=685977 \&$ _coverDate $=01 \% 2 \mathrm{~F} 31 \% 2 \mathrm{~F} 2006 \&$ _rdoc $=1 \& \_\mathrm{fmt}=$ high\&_orig $=$ search\&_sort $=\mathrm{d} \& \_$docanchor $=\& \mathrm{view}=\mathrm{c} \&$. acct $=$ C000037098\&_version $=1 \& \_u r l$ Version $=0$ \&_userid $=685977$ \& md5=a38ca064d38c978142abb17b1 ed2ec98>. Access: Nov. 10, 2006. doi: 10.1016/j.plantsci.2005.08.011.

D'AGOSTINO, L.B.; KIEBER, J.J. Molecular mechanisms of cytokinin action. Current Opinion in Plant Biology, v.2, p.359-364, 1999.

DEBNATH, M. et al. Micropropagation: a tool for the production of high quality plant-based medicines. Current Pharmaceutical Biotechnology, v.7, p.33-49, 2006.

GADZOVSKA, S. et al. Identification and quantification of hypericin and pseudohypericin in different Hypericum perforatum L. in vitro cultures. Plant Physiology and Biochemistry, v.43, p.591-601, 2005. Available in: <http:// www.sciencedirect.com/science?_ob =ArticleURL\&_udi=B6VRD4 G C W XVN-1 \&_user $=685977 \&$ _ cover Date $=$ $06 \% 2 \mathrm{~F} 30 \% 2 \mathrm{~F} 2005 \&$ _rdoc $=1 \&$ \&mt $=$ high\&_orig $=$ search\&_sort $=d \& \_d o c a n c h o r=\& v i e w=c \& \_a c c t=C 000037098 \& \_v e r s i o n=1 \&$. urlVersion=0\&_userid=685977\&md5=ac269993dfcd43d3a44b8419e8bb 187a〉. Access: Jul. 17, 2005. doi:10.1016/j.plaphy.2005.05.005 
.KARPPINEN, K. et al. In vitro propagation of Hypericum perforatum $\mathrm{L}$. and accumulation of hypericins, pseudohypericin and phologlucinols. Propagation of Ornamental Plants, v.6, p.170-179, 2006.

LIU, X-N. et al. Effects of cytokinins and elicitors on the production of hypericins and hyperforin metabolites in Hypericum sampsonii and Hypericum perforatum. Plant Growth Regulation, v.53, p.207-214, 2007. Available in: <http://www.springerlink.com/content/ f7215168477k7q41/>. Access: Jan. 29, 2008. doi: 10.1007/s10725-007-9220-0.

MACHADO, J.A.G. et al. Quantificação de flavonóides em culturas in vitro de Hypericum perforatum L. (Hypericaceae). Brazilian Journal of Bioscience, v.5, p.432-434, 2007. Available in: <http://www6.ufrgs.br/seerbio/ojs/index.php/rbb/ issue/view/23>. Access: Jan. 20, 2008.

MAURMANN, N. et al. Improved nutrient medium for biomass and valepotriate production in extended period stock cultures of Valeriana glechomifolia. In Vitro Cellular and Developmental Biology - Plant, v.44, p.209-215, 2008. Available in: <http:// www.bioone.org/doi/pdf/10.1007/s11627-008-9104-7>. Access: Nov. 29, 2009. doi: 10.1007/s11627-008-9104-7.

MURASHIGE, T.; SKOOG, F. A revised medium for rapid growth and bioassays with tobacco tissue cultures. Physiologia Plantarum, v.15, p.473-497, 1962.

PASQUA, G. et al. Metabolites in cell suspension cultures, calli, and in vitro regenerated organs of Hypericum perforatum cv. Topas. Plant Science, v.165, p.977982, 2003. Available in: <http://www.sciencedirect.com/ science?_ob=ArticleURL\&_udi=B6TBH-491R9SD$1 \& \_u s e r=685977 \&$ _coverDate $=11 \% 2 \mathrm{~F} 30 \% 2 \mathrm{~F} 2003 \&$ \&doc $=1 \&$ _ $\mathrm{fmt}=$ high $\& \_$orig $=$search \&_sort $=\mathrm{d} \& \_$docanchor $=\& \mathrm{view}=\mathrm{c} \& \_$acct
$=$ C000037098\&_version $=1 \& \_u r l$ Version=0\&_userid $=685977 \& \mathrm{md}$ $5=81062 \mathrm{cb} 8467 \mathrm{~b} 0486 \mathrm{e} 1128 \mathrm{~b} 865 \mathrm{bc} 4 \mathrm{~b} 056>$. Access: Aug. 02, 2007. doi: 10.1016/S0168-9452(03)00275-9.

POIATTI, V.A.D. et al. Defense mechanisms of Solanum tuberosum $\mathrm{L}$. in response to attack by plant-pathogenic bacteria. Biological Research, v.42, p.205-215, 2009. Available in: <http://www.scielo.cl/pdf/bres/v42n2/art09.pdf >. Access: Sept. $25,2009$.

SANTAREM, E.R.; ASTARITA, L.V. Multiple shoot formation in Hypericum perforatum L. and hypericin production. Brazilian Journal of Plant Physiology, v.15, p.43-47, 2003. Available in: <http://www.scielo.br/scielo.php?pid=S167704202003000100006\&script=sci_arttext $>$. Access: Jan. 30, 2004. doi: 10.1590/S1677-04202003000100006.

SCHMÜLLING, T. et al. Cytokinins as regulators of gene expression. Physiologia Plantarum, v.100, p.505-519, 1997.

WOJCIK, A.; PODSTOLSKI, A. Leaf explant response in in vitro culture of St. John's wort (Hypericum perforatum L.). Acta Physiologiae Plantarum, v.29, p.151-156, 2007. Available in: < http://www.springerlink.com/content/c42rh661x4073572>. Access: Jan. 29, 2008.

ZOBAYED, S.M.A. et al. In vitro production and chemical characterization of St. John's wort (Hypericum perforatum L. cv. 'New Stem'). Plant Science, v.166, p.333-340, 2004. Available in: <http://www.sciencedirect.com/ science?_ob=ArticleURL\&_udi=B6TBH-4B6CTD 7 $1 \&$ _user $=685977 \&$ _coverDate $=02 \% 2 \mathrm{~F} 29 \% 2 \mathrm{~F} 2004 \&$ \&doc $=1 \&$ _fmt $=$ high\&_orig $=$ search\&_sort $=d \& \_d o c a n c h o r=\& v i e w=c \&$. searchStrId $=1326885512 \&$ _rerunOrigin $=$ google $\& \_$acct $=\mathrm{C} 00003$ $7098 \&$ \&version $=1 \&$ \&urlVersion=0\&_userid $=685977 \& \mathrm{md} 5=99 \mathrm{a} 9 \mathrm{ebc}$ 68417abb5eec80d3c9a437fb4>. Access: Apr. 29, 2004. 